\title{
PENGARUH PENGURANGAN INTENSITAS RADIASI MATAHARI TERHADAP PERTUMBUHAN DAN KUALITAS SELADA ROMAINE (Lactuca sativa var. Longifolia)
}

\section{EFFECT OF REDUCING INTENSITY OF SOLAR RADIATION ON THE GROW TH AND QUALITY OF ROMAINE LETTUCE (Lactuca sativa var. Longifolia)}

\author{
Fransio Hutagalung ${ }^{1 *}$, Paul B Timotiwu ${ }^{2}$, Yohannes Cahya Ginting ${ }^{1}$, Tumiar Katarina B Manik ${ }^{2}$ \\ ${ }^{1} J u r u s a n$ Agroteknologi Fakultas Pertanian Universitas Lampung, Bandar Lampung, Indonesia \\ ${ }^{2}$ Jurusan Agronomi dan Hortikultura Fakultas Pertanian Universitas Lampung, Bandar Lampung, Indonesia \\ *Email: Fransiohutagalung@gmail.com \\ *Corresponding Author, Diterima: 15 Feb. 2021, Direvisi: 12 Apr. 2021, Disetujui: 24 Mei 2021
}

\begin{abstract}
The cultivation of romaine lettuce in the lowlands will face obstacles namely the intensity of solar radiation and high air temperatures which can reduce plant growth and quality. One effort to overcome this problem is to reduce the intensity of solar radiation using shade. The objectives of the study were to determine the effect of using plastic shade on (a) the changing of solar radiation intensity, air temperature, and humidity, and (b) the growth and quality of romaine lettuce plants. The research was conducted on the land Gulak Galik, Teluk Betung, Bandar Lampung. The treatments were without shade (control) and shade using plastic house (14\% UV-filter) and each treatment had 30 samples. Data intensity of solar radiation, air temperature, and humidity are displayed in graphics, while data on plant growth and yield are tested with t-test at $\alpha 0,05$. The results showed that the shade effectively reduce the intensity of solar radiation but not air temperature and humidity. The intensity of solar radiation reduced by 43\%, from

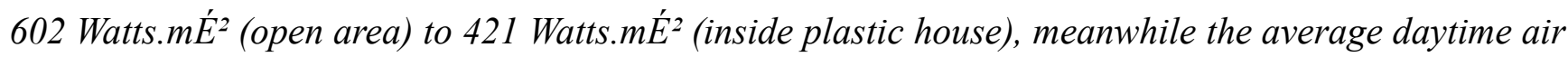
temperature inside and outside the plastic house was around $36 U \dot{C}$, and daytime humidity inside and outside the shade was 58\% and 54\%. Plants grown inside plastic house had higher stem lengths, but had lower plant fresh weight, number of leaves, leaf width, and root dry weight in compare to those grown in open area. Leaf length was not significantly different on both conditions. Although plant grown in open area had better appearance, the qualities of romaine lettuce based on color, taste, and crispness of leaves were better in plants grown inside plastic house.
\end{abstract}

Keywords: Air humidity, air temperature, intensity of solar radiation, romaine lettuce, UV plastic shade.

\begin{abstract}
ABSTRAK
Budidaya selada romaine di dataran rendah akan menghadapi kendala yaitu intensitas radiasi matahari dan suhu udara yang tinggi yang dapat menurunkan pertumbuhan dan kualitas tanaman.Salah satu usaha yang dapat dilakukan untuk mengatasi hal ini adalah dengan mengurangi intensitas radiasi matahari menggunakan naungan. Penelitian ini bertujuan untuk mengetahui pengaruh penggunaan naungan plastic penyaring UV dalam mengurangi intensitas radiasi matahari dan pengaruhnya terhadap suhu dan kelembaban udara juga untuk mengetahui pertumbuhan dan
\end{abstract}


kualitas selada romaine di dalam naunganplastik UV 14\% sebagai suatu alternative pengembangan selada di dataran rendah. Penelitian dilaksanakan di Desa Gulak Galik, Kecamatan Teluk Betung, Bandar Lampung dengan perlakuan tanpa naungan dan perlakuan penggunaan naungan plastik penyaring UV 14\%, masing-masing perlakuan memiliki 30 sampel. Data intensitas radiasi matahari, suhu udara, dan kelembaban udara ditampilkan dalam bentuk grafik sedangkan data pertumbuhan dan hasil tanaman diuji menggunakan analisis Uji-t taraf $\alpha 5 \%$. Hasil penelitian menunjukkan bahwa plastikUV yang digunakan efektifmenurunkan intensitas radiasi matahari, namun tidak secara signifikan merubah suhu udara dan kelembaban udara. Rata-rata naungan plastik penyaring UV yang digunakan menurunkan intensitas radiasi matahari dari $602 \mathrm{Watts}^{\mathrm{mE}} \mathrm{E}^{2}$ menjadi $421 \mathrm{Watts}^{\mathrm{mE}} \mathrm{E}^{2}(43 \%)$, rata-rata suhu udara siang hari di dalam dan di luar naungan yaitu sekitar 36ÚC, dan kelembaban udara siang haridi dalam dan di luar naungan yaitu 58\% dan 54\%. Penggunaan naungan plastik menghasilkan menghasilkan panjang batang yang lebih tinggi, namun untuk bobot segar tanaman, jumlah daun, lebar daun dan bobot kering akar yang lebih rendah dari pada tanaman dengan perlakuan tanpa naungan, sedangkan untuk panjang daun anatara kedua perlakuan tidak menghasilkan pengaruh yang berbeda nyata. Berdasarkan pengamatan kualitas selada romaine yang berada di dalam naungan menghasilkan warna, rasa, serta kerenyahan daun yang lebih baik daripada tanaman yang berada di luar naungan, namun untuk tampilan kanopi kepadatan tanaman lebih baik pada tanaman yang berada di luar naungan.

Kata kunci : Naungan plastik UV, radiasi matahari, selada romaine, suhu dan kelembaban udara.

\section{PENDAHULUAN}

Pertumbuhan tanaman dipengaruhi oleh faktor lingkungan. Radiasi matahari adalah salah satu faktor abiotik yang dapat mempengaruhi metabolisme dan pertumbuhan tanaman. Radiasi matahari merupakan sumber energi untuk proses fotosintesis. Radiasi matahari juga mempengaruhi suhu, semakin tinggi intensitas radiasi maka suhu udara akan semakin meningkat. Suhu dan radiasi matahari sangat penting bagi pertumbuhan dan perkembangan tanaman.

Selada romaine merupakan sayuran yang berasal dari daerah beriklim subtropis, diduga berasal dari Asia Barat atau Amerika (Haryanto, 2003). Indonesia yang termasuk Negara tropis akan menerima pancaran matahari yang terik secara terus menerus sepanjang tahun karena terletak di sepanjang kawasan garis khatulistiwa. Oleh sebab itu di Indonesia umumnya selada romaine dibudidayakan di dataran tinggi yang memiliki suhu udara lebih rendah. Terbatasnya luasan lahan dataran tinggi menjadi salah satu faktor pembatas pengembangan sayuran yang adaptif di dataran tinggi. Oleh sebab itu, selada yang biasanya diproduksi di dataran tinggi perlu diupayakan di dataran rendah. Dalam budidaya sayuran dataran tinggi di dataran rendah akan menghadapi kendala yaitu suhu udara yang terlalu tinggi yang dapat mempercepat penuaan (senesens) sehingga pertumbuhan dan hasil tanaman menjadi tidak optimal. Salah satu usaha yang dapat dilakukan untuk mengatasi hal ini adalah dengan mengurangi intensitas radiasi matahari menggunakan naungan.

Penelitian ini bertujuan untuk mengetahui pengaruh penggunaan naungan plastik penyaring UV dalam mengurangi intensitas radiasi matahari dan pengaruhnya terhadap suhu dan kelembaban udara juga untuk mengetahui pertumbuhan dan kualitas selada 
romaine di dalam naungan plastik UV 14\% sebagai suatu alternative pengembangan selada di dataran rendah.

\section{BAHAN DAN METODE}

Penelitian ini dilaksanakan di lahan percobaan Kelurahan Gulak Galik, Kecamatan Teluk Betung Utara, Bandar Lampung dengan ketinggian tempat 10 m di atas permukaan laut, pada bulan Mei sampai dengan Juni 2019. Terdapat dua perlakuan, yaitu tanpa naungan, dan perlakuan penggunan naungan plastik UV 14\%, masing-masing perlakuan memiliki 30 sampel tanaman. Naungan yang digunakan memiliki tinggi 2 $\mathrm{m}$, lebar 1,5 m, dan panjang $2 \mathrm{~m}$. Data yang diperoleh dari hasil pengamatan tiap variabel pertumbuhan tanaman dianalisis menggunakan Uji-T dengan tarafá $5 \%$, dan hasil pengamatan intensitas radiasi matahari, suhu udara, dan kelembaban udara disajikan dalam bentuk grafik. Bahan-bahan yang digunakan adalah benih selada romaine, tanah, kompos, pupuk dasar NPK dan Urea. Alat yang digunakan yaitu bambu, tali plastik, paku, palu, linggis, gunting, plastik penyaring UV 14\% yang memiliki ketebalan 200 mikron dengan lebar $3 \mathrm{~m}$, polybag $3 \mathrm{~kg}$, cangkul, selang air, ember, label sampel, penggaris, meteran, pyranometer, thermohygrometer, dan alat laboratorium untuk analisis tanaman. Pengukuran intensitas radiasi matahari, suhu, dan kelembaban dilakukan di dalam dan di luarnaungan pada siang hari sekitar pukul 12.00-13.00 WIB, mulai dari awal pindah tanam hingga panen. Pengamatan tambahan juga dilakukan selama 1 minggu setelah panen pada jam 07.00 WIB, 12.00 WIB dan 17.00 WIB untuk melihat perbandingan intensitas radiasi matahari, suhu udara dan kelembaban udara pagi, siang, dan sore hari, dan hasilnya ditampilkan dalam bentuk grafik.

\section{HASIL DAN PEMBAHASAN}

Naungan plastik penyaring UV yang digunakan efektifmenurunkan intensitas radiasi matahari siang hari dari 602 Watts. $m^{-2}$ menjadi 421 Watts.m ${ }^{-2}$ (Gambar 1). Perbedaan intensitas radiasi matahari pagi, siang, dan sore dapat dilihat pada Gambar 2 yang menunjukkan bahwa intensitas radiasi matahari yang masuk ke dalam naungan pada pagi hari turun sebesar $46 \%$, siang hari sebesar 38\%, dan sore hari sebesar 28\%.

Penggunaan naungan plastik penyaring UV 14\% yang efektif mengurangi intensitas radiasi matahari

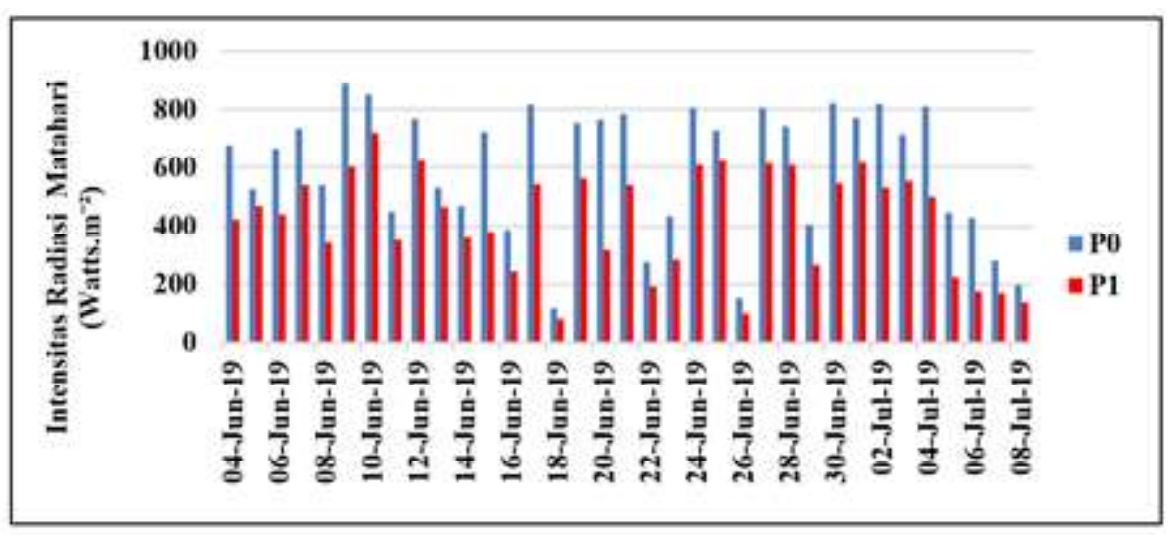

Gambar 1. Grafik hasil pengukuran intensitas radiasi matahari perlakuan kontrol dan penggunaan naungan plastik penyaring UV 14\%. 
diharapkan mampu mengubah suhu udara dan kelembanban udara di dalam naungan. Hasil rata-rata pengukuran suhu udara pada siang hari (Gambar 3) pada kedua perlakuan hamper sama yaitu sekitar 36 ${ }^{\circ} \mathrm{C}$. Berdasarkan perbedaan suhu udara pagi, siang, dan sore hari (Gambar 4) diketahui bahwa tingginya suhu udara berbanding lurus dengan intensitas radiasi matahari. Menurut Mayer dan Anderson (1952) dalam Dewi (2017), bahwa semakin besar intensitas radiasi yang diterima ke permukaan bumi, maka suhu udara di permukaan akan semakin tinggi, sebaliknya semakin rendah intensitas radiasi matahari yang diterima ke permukaan bumi, maka suhu udara di permukaan akan semakin rendah.

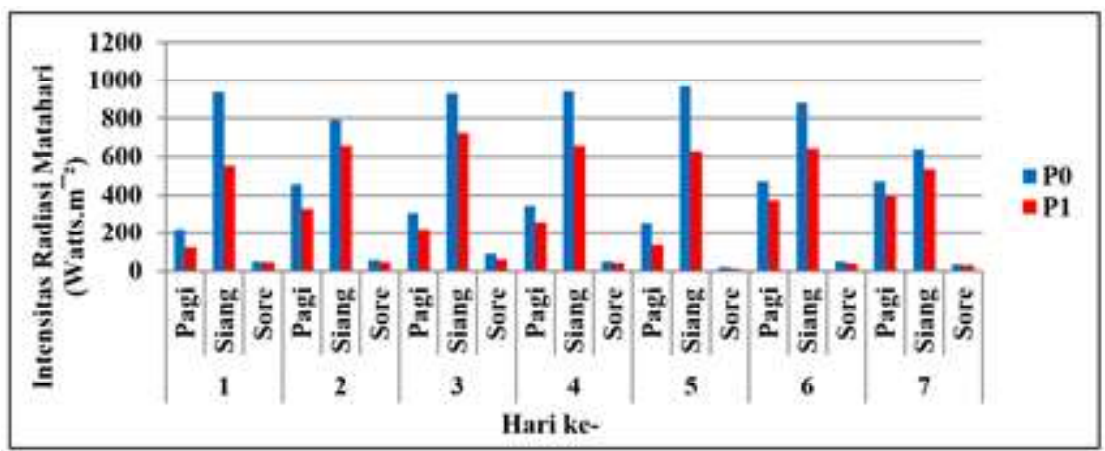

Gambar 2. Grafik perbedaan hasil pengukuran intensitas radiasi matahari pagi, siang, dan sore hari perlakuan kontrol dan penggunan naungan plastik penyaring UV 14\%.

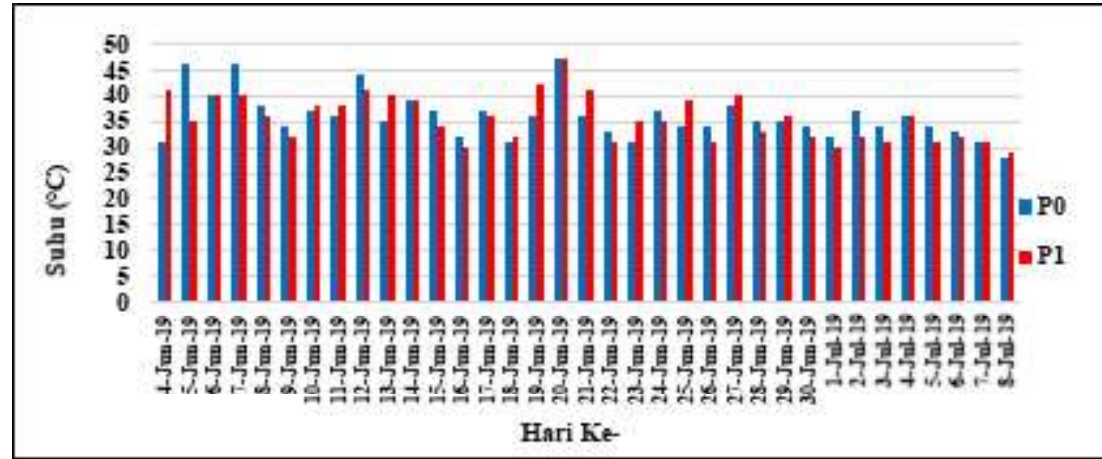

Gambar 3. Grafik hasil pengukuran suhu udara kontrol dan penggunaan naungan plastik penyaring UV 14\%.

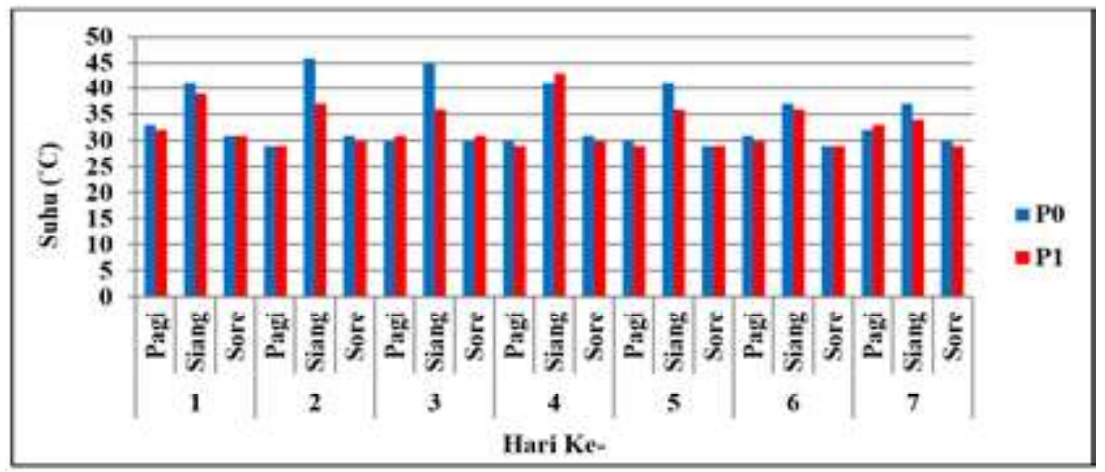

Gambar 4. Grafik perbedaan hasil pengukuran suhu udara pagi, siang, dan sore hari perlakuan kontrol (P0) dan penggunaan naungan plastik penyaring UV 14\%(P1). 
Penyebab suhu udara di dalam naungan tetap tinggi adalah akibat adanya radiasi balik dari permukaan tanah dalam bentuk gelombang panjang yang tidak dapat menembus lapisan plastik. Meskipun naungan tidak sepenuhnya tertutup, tetapi karena ketinggian naungan yang rendah maka angin tidak dapat memindahkan energi panas yang berada di dalam naungan. Selain itu, naiknya suhu pada naungan dapat juga 8a disebabkan oleh lebih intensifnya gelombang panjang yang dipancarkan kedalam naungan (Suhardiyanto, 2009).

Hasil pengukuran rata-rata kelembaban udara di dalam dan di luar naungan berkisar 58\% dan 54\% yang berarti udara cukup kering (Gambar 5). Salah satu penyebab rendahnya kelembaban udara di dalam naungan yaitu kurangnya penyiraman yang dilakukan sehingga tanah menjadi kering. Rata-rata suhu udara yang tinggi di dalam naungan seharusnya mengakibatkan laju evaporasi meningkat dan kelembaban udara juga meningkat, namun karena tanah telah berada dalam keadaan kering maka tidak ada lagi kelembaban yang dapat diuapkan, sehingga udara menjadi kering (kelembaban rendah). Berdasarkan Gambar 6 dapat dilihat bahwa kelembaban udara pada siang hari mengalami penurunan. Menurut Sudaryono (2004), hal ini terjadi karena pada siang hari intensitas radiasi matahari yang diterima tanaman relatif tinggi, yang menyebabkan kandungan air dalam tanaman berkurang

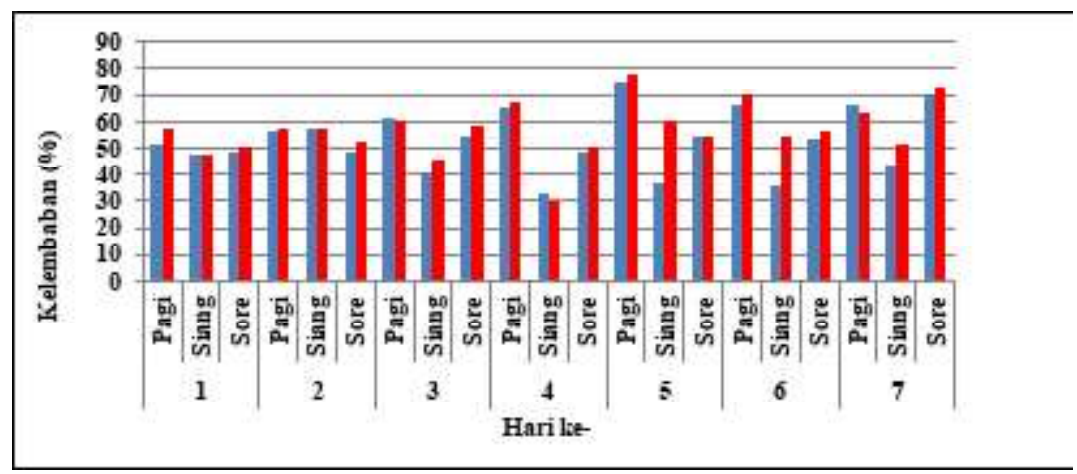

Gambar 5. Grafik hasil pengukuran kelembaban perlakuan kontrol(P0) dan penggunaan naungan plastik penyaring UV 14\% (P1).

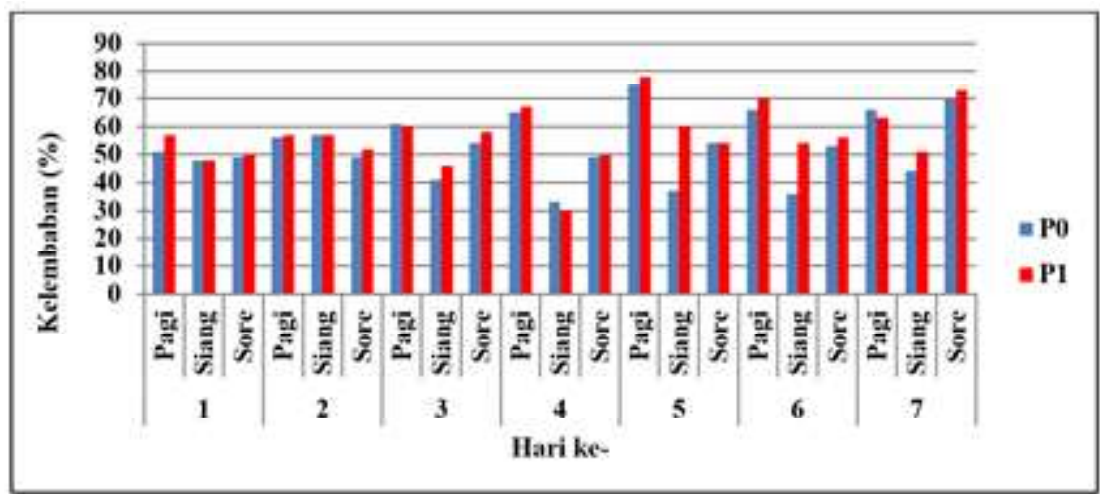

Gambar 6. Grafik perbedaan hasil pengukuran kelembaban udara pagi, siang, dan sore hari perlakuan kontrol (P0) dan penggunaan naungan plastik penyaring UV 14\% (P1). 
karena mengalami evaporasi sehingga tekanan uap udara semakin rendah yang menyebabkan kelembaban udara juga menjadi rendah.

Hasil Uji-T(Tabel 1) menunjukkan penggunaan naungan plastik penyaring UV 14\% memberikan pengaruh berbeda yang sangat nyata terhadap jumlah daun, panjang batang, bobot segar tanaman, dan bobot kering akar serta memberi pengaruh berbeda nyata terhadap lebar daun. Hal tersebut ditunjukkan dengan nilai $p$ value untuk variabel pengamatan, jumlah daun, panjang batang, bobot segar tanaman, dan bobot kering akar yang lebih kecil dari $\alpha 0,05(0,0000005<$ $0,05)$ dan untuk variabel lebar daun memiliki $p$ value yang lebih kecil dari $\alpha 0,05(0,005<0,05)$. Namun demikian, untuk variabel panjang daun memiliki nilai $p$ value yang lebih besar dari $\alpha$ 0,05 dengan kata lain penggunan naungan tidak berpengaruh nyata terhadap panjang daun selada romaine.

Tanaman yang berada di luar naungan menghasilkan bobot segar tanaman yang lebih tinggi. Kondisi ini menunjukkan bahwa tanaman selada membutuhkan cahaya yang penuh untuk mendukung pertumbuhannya. Tingginya bobot segar tanaman pada perlakuan tanpa naungan ini didukung dengan hasil jumlah daun, diameter batang, luas daun dan volume akar tanaman yang lebih tinggi daripada tanaman dengan perlakuan naungan. Berkurangnya energi cahaya matahari di dalam naungan menyebabkan pertumbuhan tanaman terganggu sehingga produksi biomassa tanaman menjadi rendah

Jumlah daun tanaman yang berada di dalam naungan lebih sedikit dibandingkan jumlah daun pada tanaman di luar naungan. Rata-rata jumlah daun yang dihasilkan tanaman di luar naungan mencapai 34,07 helai, sedangkan jumlah daun tanaman di dalamnaungan hanya mencapai 24,83 helai. Penggunaan naungan juga menyebabkan lebar daun tanaman selada romaine menjadi lebih rendah. Hal ini karena semakin berkurangnya intensitas radiasi matahari yang diterima tanaman mengakibatkan proses fotosintesis menurun sehingga menghambat pertumbuhan vegetatif terutama pada daun (Musyarofah dkk., 2007).

Tabel 1. Rekapitulasi hasil Uji-t untuk pengaruh pengurangan intensitas radiasi matahari tanaman selada romine.

\begin{tabular}{|c|c|c|c|c|c|}
\hline Variabel & Perlakuan & Nilai Tengah & P-Value & T-hit & T-tab \\
\hline $\begin{array}{l}\text { Jumlah } \\
\text { Daun (helai) }\end{array}$ & $\begin{array}{l}\text { P0 } \\
\text { P1 }\end{array}$ & $\begin{array}{l}34,07 \\
24,83\end{array}$ & $0.00000000969^{* *}$ & 6,51 & 1,67 \\
\hline $\begin{array}{l}\text { Panjang } \\
\text { Batang }(\mathrm{cm})\end{array}$ & $\begin{array}{l}\mathrm{P} 0 \\
\mathrm{P} 1\end{array}$ & $\begin{array}{l}18,69 \\
23,44\end{array}$ & $0,00017^{* *}$ & -3.82 & 1,67 \\
\hline $\begin{array}{l}\text { Panjang } \\
\text { Daun }(\mathrm{cm})\end{array}$ & $\begin{array}{l}\mathrm{P} 0 \\
\mathrm{P} 1\end{array}$ & $\begin{array}{l}19,81 \\
19,86\end{array}$ & $0,179^{(\mathrm{tn})}$ & -0.93 & 1,67 \\
\hline $\begin{array}{l}\text { Lebar } \\
\text { Daun }(\mathrm{cm})\end{array}$ & $\begin{array}{l}\mathrm{P} 0 \\
\mathrm{P} 1\end{array}$ & $\begin{array}{l}12,02 \\
11,13\end{array}$ & $0,00154^{*}$ & 3.11 & 1,67 \\
\hline $\begin{array}{l}\text { Bobot Segar } \\
\text { Tanaman (gr) }\end{array}$ & $\begin{array}{l}\mathrm{P} 0 \\
\mathrm{P} 1\end{array}$ & $\begin{array}{l}251,0 \\
149,7\end{array}$ & $0,000000000364^{* *}$ & 7.36 & 1,67 \\
\hline $\begin{array}{l}\text { Bobot Kering } \\
\text { Akar (gr) }\end{array}$ & $\begin{array}{l}\mathrm{P} 0 \\
\mathrm{P} 1\end{array}$ & $\begin{array}{l}3,63 \\
1,37 \\
\end{array}$ & $0,000000088^{* *}$ & 6.98 & 1,67 \\
\hline
\end{tabular}

Keterangan: P0 = Perlakuan kontrol (tanpa naungan plastik penyaring UV 14\%), P1 = Perakuan pemberian naungan penyaring UV $14 \%, * *=$ Berbeda sangat nyata pada taraf $\alpha 5 \%, *=$ Berbeda nyata pada taraf $\alpha 5 \%$, tn $=$ Tidak berbeda nyata pada taraf $\alpha 5 \%$. 
Berdasarkan pengamatan panjang batang tanaman terlihat terjadi peningkatan panjang batang tanaman di dalam naungan. Panjang batang maksimum tanaman di dalam naungan, mencapai $36 \mathrm{~cm}$ sedangkan tanaman di luar naungan hanya mencapai $26,5 \mathrm{~cm}$. Peningkatan panjang batang tanamaan di dalam naungan ini berhubungan dengan hormon pertumbuhan tanaman yaitu auksin lebih banyak terdapat pada tempat yang terlindung dari cahaya. Karena cahaya dapat menghambat produksi hormon auksin sehingga auksin ditranslokasikan ke sisi yang terlindung dari cahaya pada tempat yang diletakan di tempat yang terang. Meskipun pada perlakuan kontrol panjang batang tanaman cenderung lebih rendah namun diameter batang tanaman tersebut lebih besar dan nampak lebih kokoh dibandingkan batang tanaman di dalam naungan.

Pada penelitian ini pengamatan kualitas tanaman hanya dilakukan secara langsung dengan mengamati sifat-sifat kualitas tanaman. Sifat-sifat yang diamati pada penelitian ini yaitu warna daun, rasa, kerenyahan, dan tampilan kepadatan kanopi tanaman. Menurut Eko dkk(1995), kualitas tanaman selada romaine yang baik ditunjukkan dengan warna hijau yang lebih terang, memiliki tekstur yang renyah, turgiditas sel/kesegaran yang tinggi serta terhindar dari kerusakan. Berdasarkan pengamatan visual yang dilakukan, daun tanaman yang berada di dalam naungan menghasilkan warna hijau yang lebih terang dibandingkan daun tanaman yang berada di luar naungan. Hal itu sejalan dengan CharlesEdward (1982) dalam Suci (2018) yang melaporkan bahwa, secara umum daun yang tumbuh di dalam lingkungan dengan intensitas cahaya rendah akan menghasilkan warna daun yang lebih terang dan memiliki permukaan daun yang lebih luas dari pada daun yang tumbuh pada tingkat intensitas cahaya yang lebih tinggi.

Berdasarkan hasil pengamatan tanaman selada romaine yang berada di luar naungan memiliki rasa yang cenderung lebih pahit dan kerenyahan daun yang relatif lebih rendah. Daun tanaman di luar naungan terlihat mengandung getah yang diduga terkandung senyawa flavonoid sehingga menyebabkan rasa pahit daun tanaman. Menurut Harbone (1987) dalam Ergina dkk., (2014), bahwa senyawa flavonoid merupakan salah

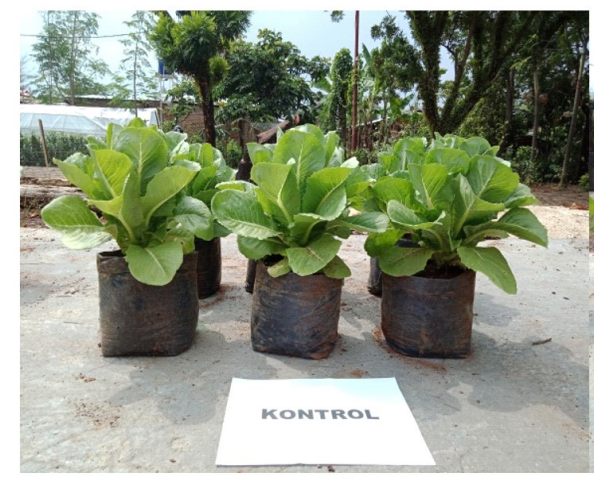

(a)

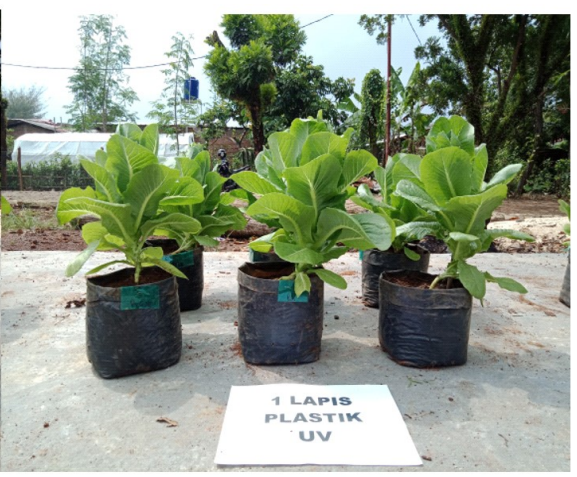

(b)

Gambar 7. Pengaruh pengurangan intensitas radiasi matahari terhadap kualitas kepadatan tanaman selada romaine (a) kepadatan tanaman perlakuan kontrol (b) kepadatan tanaman penggunaan naungan plastik penyaring UV $14 \%$. 
satu senyawa yang tergolong dalam senyawa metabolit sekunder yang muncul akibat adanya radiasi sinar ultraviolet sebagai bentuk pertahanan diri dari paparan langsung sinar matahari.

Berdasarkan pengamatan yang dilakukan daun tanaman selada romaine yang berada di dalam naungan memiliki tekstur daun yang lebih renyah karena daun yang dihasilkan lebih tipis dibandingkan daun tanaman di luar naungan. Menurut Sudaryono (2004), hal tersebut disebabkan karena intensitas radiasi matahari yang tinggi akan meningkatkan laju transpirasi yang berlebih sehingga tanaman akan kekurangan air yang mengakibatkan terhentinya proses pembelahan sel dalam tanaman, dan tanaman akan membentuk semacam lapisan lilin pada daun yang menyebabkan daun tanaman menjadi lebih tebal dan lebih kecil.

Pengamatan kualitas tanaman selada romaine juga dengan melihat tampilan kepadatan kanopi tanaman. Berdasarkan Gambar 7 tanaman yang berada di luar naungan memiliki tampilan kanopi yang lebih padat. Tampilan ini ditinjau dari jumlah daun dan diameter batang tanaman. Semakin tinggi intensitas radiasi matahari yang di terima maka jumlah daun akan semakin banyak dan diameter batang tanaman akan semakin besar. Menurunnya diameter batang pada intensitas radiasi matahari rendah sejalan dengan peryataan Daniel dkk., (2007), yang mengemukakan bahwa terhambatnya pertumbuhan diameter tanaman terjadi karena spektrum cahaya matahari yang kurang merangsang aktivitas hormon dalam proses pembentukan sel meristematik kearah diameter batang terutama pada intensitas radiasi matahari yang rendah.

\section{KESIMPULAN}

Berdasarkan hasil penelitian menunjukkan bahwa pemberian naungan plastik penyaring UV 14\% mampu menurunkan intensitas radiasi matahari dari 602 Watts.mÉ2 menjadi 421 Watts.mÉ ${ }^{2}$ namun tidak dapat merubah suhu udara dan kelembaban udara secara signifikan. Tanaman pada perlakuan tanpa naungan menghasilkan bobot segar lebih tinggi daripada tanaman di dalam naungan. Secara visual tampilan tanaman pada perlakuan kontrol lebih baik yang ditinjau dari tampilan kanopi tanaman yang lebih padat, namun karena memiliki warna daun yang hijau lebih gelap dan rasa yang lebih pahit serta tingkat kerenyahan yang rendah maka kurang diminati oleh konsumen.

\section{UCAPAN TERIMA KASIH}

Penulis mengucapkan terima kasih kepada Bapak Dr. Ir. Paul Benyamin Timotiwu, M.S., selaku dosen pembimbing utama, Bapak Ir. Yohannes Cahya Ginting, M. P., selaku pembimbing kedua, dan Ibu Dr. Ir. Tumiar Katarina B. Manik, M.Sc., selaku pembahas atas kesediaannya untuk memberikan bimbingan, saran, kritik dan motivasi, serta semua pihak yang telah berkontribusi dalam penelitian ini, sehingga penelitian dapat terlaksana dengan baik.

\section{DAFTAR PUSTAKA}

Daniel, R. M., Danson, M. J., dan Eisenthal, R. 2001. The Temperature Optima of Enzymes; A New Perspective On An Old Phenomenon. Trands Biochem Sci 26: 223-225.

Dewi, A. S. 2017. Pengaruh Intensitas Cahaya Matahari terhadap PerubahanSuhu, 
Kelembaban Udara, dan Tekanan Udara. Skripsi. Fakultas Keguruan dan Ilmu Pendidikan. Universitas Jember.

Eko, H., Tina, S., dan Estu, R. 1995. Sawi dan Selada. PT. Penebar Swadaya. Bogor.

Ergina, N. Siti., dan Indriani, D.P. 2014. Uji kualitatif senyawa metabolit sekunder pada daun palado (Agave angustifolia) yang diekstraksi dengan pelarut air dan etanol. J. Akad. Kim. 3(3): $165-172$

Haryanto. 2003. Respon Pertumbuhan dan Produktivitas Selada terhadap Volume Irigasi dan Dosis Pupuk dengan Metode Hidroponik MediaPasir. Skripsi. Institut Pertanian Bogor. Bogor.
Musyarofah, N., Susanto, S., Aziz, S. A., dan Kartosoewarno, S. 2007. Respon tanaman pegagan (Centellaasiatica L. Urban) terhadap pemberian pupuk alami di bawah naungan. Bulletin Agronomi. 35 (3); 217-224

Suci. W. C. 2018. Pengaruh intensitas cahaya terhadap keragaan tanaman puring (Codiaeum variegetum). Jurnal Produksi Tanaman. 6(1) : 161-169

Suhardiyanto, H. 2009. Teknologi Rumah Tanaman untuk Iklim Tropika Basah "Pemodelan dan Pengendalian Lingkungan”. IPB Press. Bogor.

Sudaryono. 2004. Pengaruh naungan terhadap perubahan iklim mikropada budidaya tanaman tembakau rakyat. Jurnal Teknik Lingkungan 5(1): 56-60 